\title{
FLOOD CHARACTERISTICS AND MANAGEMENT ADAPTATIONS IN PARTS OF THE IMO RIVER SYSTEM
}

\author{
${ }^{*}$ Ezemonye, M. N. ${ }^{1}$ and Emeribe, C. N. ${ }^{2}$ \\ DOI: http://dx.doi.org/10.4314/ejesm.v4i3.8 \\ Received October $13^{\text {th }} 2011$; accepted October $26^{\text {th }} 2011$
}

\begin{abstract}
This paper examined the physical characteristics of floods and management adaptations to flood hazards in the Imo River basin. From the study, it was determined that the pre and post flood disaster management is a yearly event. The extent and time of commencement usually differs in each flood season, being between July, August and September when rainfall is at its peak. From the study, it was observed that flood duration in the sampled communities last for as much as three to four months. The velocity of the floodwaters under peak discharge usually between August and September was observed to be sluggish, while being faster during recession in mid-October. An investigation of human adaptation to flooding in affected communities indicated that up to $70 \%$ of the inhabitants have derived ways of managing their flood disasters on short term basis. These adaptation methods include emergency evacuation and rescheduling of activities, bearing flood losses and land use changes. It is recommended flood forecasting and warming systems be introduced. Engineering control of the major tributaries of the Imo River system is required to reduce impact of flooding on the settlements, while land use zoning will serve as an effective adaptation and disaster management option in the study area.
\end{abstract}

\section{Keywords: Flood disaster, climate change, weather extremes, management strategies}

\section{Introduction}

In the past quarter century over $95 \%$ of disaster deaths occurred in developing countries, and direct economic losses income were more than doubled in low-income and high-income countries (Arnold and Kreimer, 2004). Disasters are 'situations or events which overwhelm local capacity, necessitating a request to a national or international level for external assistance; an unforeseen and often sudden events that cause damage, destruction and human suffering' (CRED 2010). According to study by CRED (2010) about 335 natural disasters (excluding biological disasters) were reported globally in 2009. More so, 11 000 persons were killed and 119 million others were affected by these disasters. The economic damages associated with these natural disasters were estimated to be just over US\$ 40 billion. Hydrological disasters (e.g. floods) $(54 \%)$ remained the most common disasters in 2009, followed by meteorological disasters (e.g. storms) (25\%).
For developing countries such as make up the African continent, the weakness of State infrastructures, absence of appropriate legal and policy frameworks and sometimes inadequate resources particularly render them more vulnerable to the gory consequences of largescale disasters. (Olowa, 2010). Two thirds of the coastal disasters recorded each year are associated with extreme weather events such as storms and floods. These are likely to become more pervasive threats due to shifts in climate and sea level rise (Adger et al., 2005). In terms of coastal flooding it is estimated that about 50 million people are estimated to be at such risk by 2080 due to climate change and increasing population densities.

Floods are the most common and widespread of all-natural disasters (Bhanumurthy and Behera, 2008). Flooding accounts for about $40 \%$ of fatalities from natural disasters. Future developments may lead to a growth of the

\footnotetext{
${ }^{I}$ Department of Geography and Regional Planning, University of Benin, Benin City, Nigeria

${ }^{2}$ Environmental Pollution /Remediation Unit of the National Centre for Energy and

Environment, Energy Commission of Nigeria, University of Benin, Benin city.

Corresponding author email: ezemonyemary@yahoo.com
} 
worldwide risks of flooding. The effects associated with global warming, such as sea level rise, more intensive precipitation levels and higher river discharges, may increase the frequency and the extent of flooding on a worldwide scale. Increased urbanization in developing countries and invasion of coastal and river plain areas by agricultural, residential and industrial activities, etc., are some of the major factors that will contribute to the increased vulnerability to flood hazards.

Floods occur when soil becomes saturated and its infiltration capacity is zero; runoffs cannot be contained in stream channels, natural ponds and constructed reservoirs, and the land surface becomes submerged, sweeping away all its content. Periodic floods, resulting during heavy rains, occur naturally on many rivers, forming an area known as the flood plain. The river floods often cause the rivers to overflow their banks, sometimes with a velocity and enormously destructive surge. Global population growth, more intensive urbanization in flood prone areas and the limited development of sustainable flood-control strategies will increase the (potential) impacts of floods (Jonkman, 2004).

Every year floods cause enormous damage all over the world. In the last decade of the 20th century floods killed about 100,000 persons and affected over 1.4 billion people. The statistics show that floods have a large impact on human well-being on a global scale. As a direct consequence floods may lead to economic damage and damages to ecosystems and historical and cultural values. Furthermore floods can lead to the loss of human life and other (non-lethal) human health effects, (Ohl and Tapsell, 2000; WHO, 2002; Hajat et al., 2003). Indirectly floods can cause the loss of economic and agricultural production and a decrease of socio-economic welfare (Appleton, 2002). In response, the International Decade for Natural Disaster Reduction (IDNDR) was launched by the General Assembly of the United Nations in 1987 to run from 1990 to 2000. Its aim is to reduce the loss of life, property damage and social and economic disruption caused by natural disasters. The resolution proclaiming the Decade makes specific reference to floods, tsunamis, drought and desertification among the principal disasters to be considered. The IDNDR calls for action by governments and international organizations to put greater emphasis than in the past on disaster prevention (Ologunorisa, 2009).

Natural disasters are inevitable and it is almost impossible to fully recoup the damage caused by the disasters. But it is possible to minimize the potential risk by developing early disaster warning strategies, preparing and implementing developmental plans to provide resilience and to help in rehabilitation ((Bhanumurthy and Behera, 2008). In response to global natural disasters being witnessed the Federal government in 1976 established the National Emergency Relief Agency (NERA) to coordinate its disaster response activities. The Agency was purely a relief organization focusing only on post disaster management. The continued increase in deaths from natural and man-made disasters globally highlighted the dare need for mitigation and prevention of disasters. Thus in 1999, the National Emergency Management Agency (NEMA) was established to replace NERA and to manage disasters in Nigeria in its entire ramification. The National Emergency Management Agency, amongst others, has a mandate to Formulate policy on all activities relating to disaster management in Nigeria and co-ordinate the plans and programmes for efficient and effective response to disaster at national level. Since its formation however, not much has not been achieved due to the weak state of infrastructures, absence of appropriate legal and policy frameworks and sometimes inadequate resources and capacity building in the country.

Nigeria in the last two decades has witnessed tremendous increase in the population of coastal areas, which place more people at the risk of extreme weather events especially flooding. Serious flood disasters are known to have occurred in Ibadan (1985, 1987. 1990), Osogbo, Osun State (1992, 1996, 2002), Yobe (2000), Akure, (1996, 2000, 2002, 2004, 2006) and the coastal cities of Lagos, Portharcourt, Calabar, Uyo and Warri among many incidences that have claimed many lives and properties worth millions of naira (Eludoyin et al., 2007).

The flood events in most southern cities in Nigeria are so prominent that some inhabitants in many of these settlements have often described it as 'an act of God'. However, apart from the Yobe's case, which was caused by breakdown of a dam, flood events in many capital cities in Nigeria, 
including Akure, Ibadan, Lagos and Osogbo are mostly due to the poor consciousness of the inhabitants on environmental information, inadequate (or sometimes absolute lack) of spatial information on the flood prone areas, waste dump and construction of buildings (both commercial and residential, even public offices) on river channel without adequate measure for water flow (Eludoyin et al., 2007). While the poor will be most vulnerable to the flood disaster disasters, it is often the women and children among them who are most affected.

In view of the devastating impacts of floods and associated socio-economic consequences plus the potential impacts of extreme weather events occasioned by shift in climate, there need to study the character of floods and evaluate the existing adaptation measures to flood hazard in Nigeria becomes necessary. The present study seeks to examine the physical character of floods and evaluate adaptation measures already adopted in flood prone areas. This is with a view to introducing other measures that will aid in flood disaster reduction in flood prone areas.

\section{Study Area}

The Otamiri and Oramirukwa Rivers form the study area. The two Rivers are major tributaries of the Imo River and lie about $60 \mathrm{kms}$ north of the Atlantic Ocean and $70 \mathrm{kms}$ east of the River Niger. The area is located within latitudes $05^{\circ} 25^{\prime} \mathrm{N}$ and $05^{\circ}$ $32^{\prime} \mathrm{N}$ and Longitudes $06^{\circ} 56^{\prime} \mathrm{E}$ and $07^{\circ} 35^{\prime} \mathrm{E}$. The topography of the study area is generally plain in the south but consist of gentle to high undulating ridges in the North. The study area is underlain by coastal plains sands of the Miocene-Pleistocene stage. The sediments consist of yellow and white sands which are sometimes cross-bedded with clays and sandy clays occurring in lenses (Orajaka, 1975). The soils found in the study area are the deep porous brown and red soils derived from sands. These soils belong to the class of ferralitic soils.

Two communities within the catchment areas of Otamiri and Oramiriukwa were chosen for the study. These are Nekede and Ulakwo communities both in Imo State. The Otamiri river is gauged at Nkede while Oramiriukwa rive is gauged at Ulakwo (Fig. 1).

The vegetation of the basins can be described as secondary forest. The vegetation cover shows a varied combination of different types of plant group which reflect the extent of interference by man on the original vegetation cover. In some parts of the basin, the vegetation cover are marked by the frequent occurrence of the umbrella tree (Musanga decropoides). The southern part of both basins is relatively undisturbed. The forest is dense and consists of 3 layers; high dominant trees, low dominant trees, shrubs and herds all interwoven by lianas and climbers. Tress here attains the heights of between 25-30meters. In the middle section of the Otamiri basin, different species of shrubs with heights of 3.5-5 meters form the dominant vegetation cover. The common species found includes Acio barter and Dialum guineensis species.

\section{Methodology}

Available stream discharge data for selected communities for the periods 1984 to 1988 were obtained from the Hydrological Year Book of the Anambra-Imo River Drainage Basin Development Authority (A.I. R.D.B D.A, 1984). These data were extended by 22 years using the SCS-CN model by USDA Soil Conservation Service (SCS, 1972). CN values for our study area were directly estimated from available discharge data of the study area, using Hawkings (1979) quadratic formula. The SCS-CN method is based on the water balance equation and on the fundamental assumption that the ratio of runoff to effective rainfall is the same as the ratio of actual retention to potential retention (Soulis et al., 2009). Rainfall data of the study area were collected from the Nigeria Meteorological Agency, for the periods 1982 to 2010. Oral interviews, Focus group discussion and questionnaire techniques were adopted to capture information of existing adaptation measures to flood events. Information on flood characteristics in the two communities was determined from hydrographs drawn for the areas such as flood magnitudes, flood peak period, flood recession as well as information on process-response relationships in the two basins (rainfall-stream flow relationship). The Coefficient Variability (C.V) index was used to compute the percentage variation in stream discharge in the study area. The general trends and direction in stream discharge of the rivers under study was determined using regression and correlation techniques of Pearson Product Moment Correction (Moroney, 1964). 


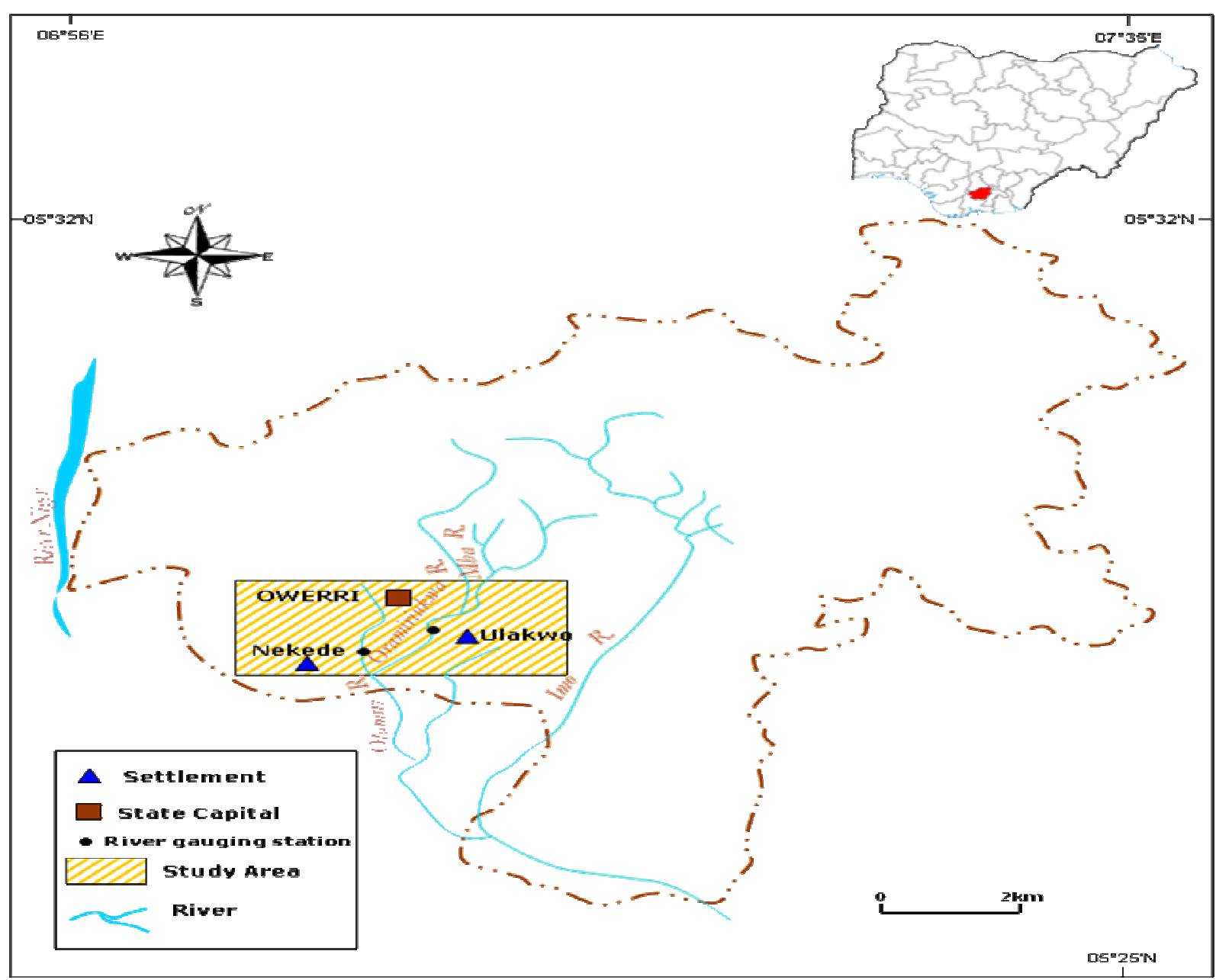

Fig. 1 Map of Imo State showing study area.

\section{Results and Discussion}

The results of computed monthly stream flows and seasonal pattern of discharge in the studied communities are presented below.

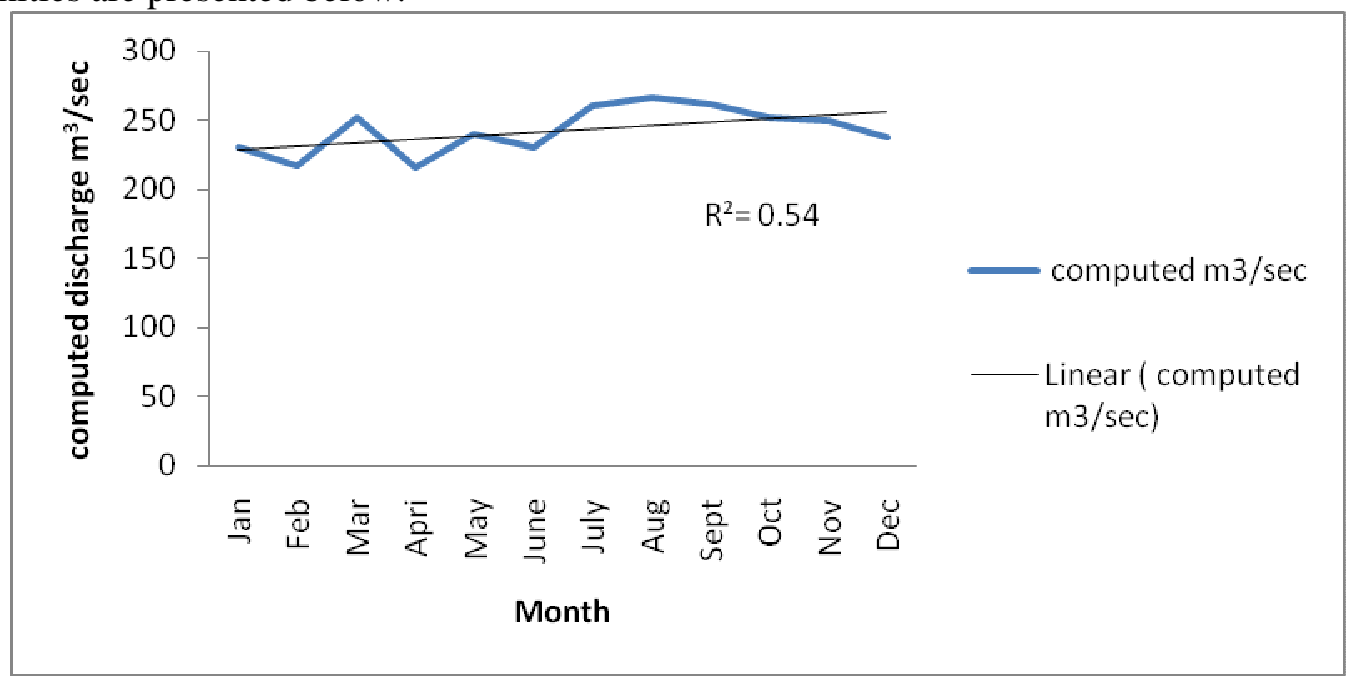

Fig.2 Seasonal stream flow pattern of Otamiri in Nekede Community 


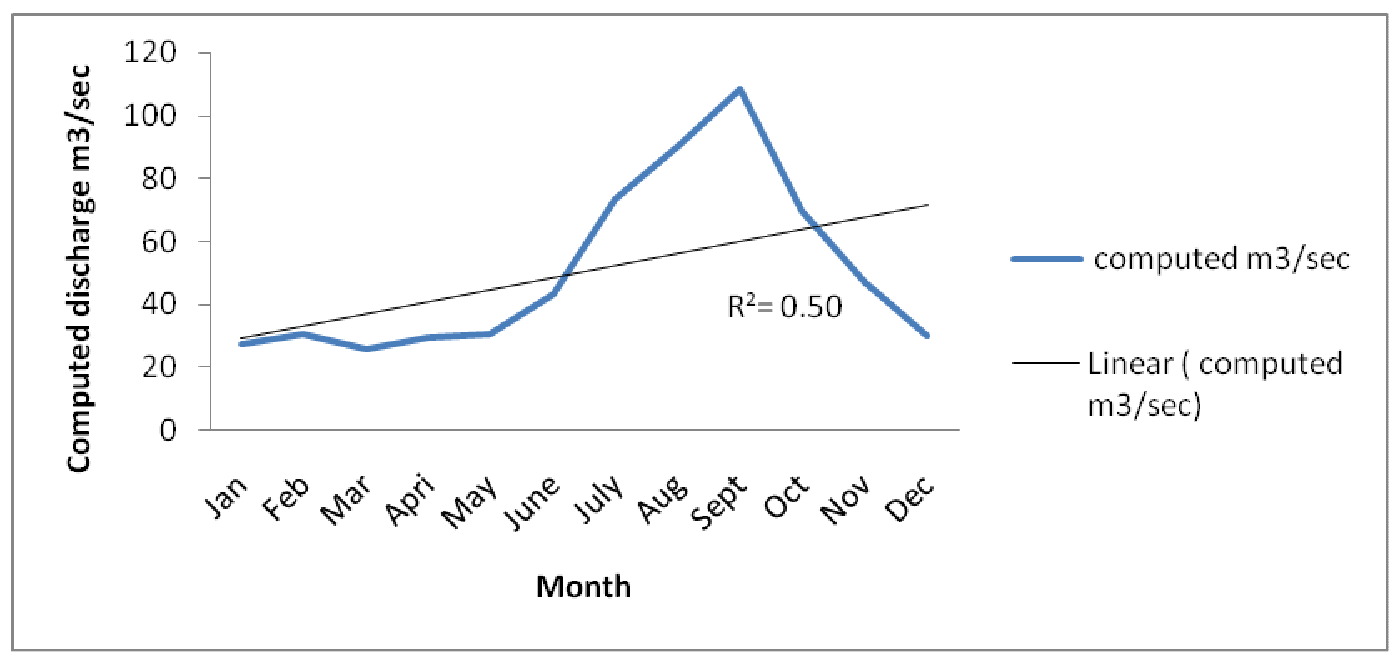

Fig.3: Seasonal stream flow pattern of Oramiriukwa in Ulakwo Community

In Fig.2, high discharge values were attained from the month of July and maintained through August to September. Soil moisture recharge in Otamiri basin spanned from May to July. The sudden rise in discharge as observed in March represents flash flood which is associated with early rains in the basin. Trend in stream discharge of Otamiri shows a general linear suggesting that flooding in Nekede was seasonal with a coefficient value of 0.54 . Thus, the greater the amount of precipitation, the greater the expansion of source areas contributing quick flow to the stream channels, which eventually spills over to adjacent land resulting in flooding.

Duration of flood represents the length of time an area is under peak. In Fig. 2, Nekede becomes flooded after the Otamiri river had attained its bank full stage between July to September with August recording the highest peak. The volume of discharge during flood months in Nekede include 259.9 (July), 266.3(August) and 261(September) $\mathrm{m}^{3} / \mathrm{sec}$. In Fig. 3 , peak discharges were recorded between August and September. The pattern of stream discharge of Oramirikwa like Otamiri River shows a general linear trend with a coefficient (r) of 0.50. Flood duration in Ulakwo community, spans from August through September, with monthly discharge volumes of 90.5 and $108.3 \mathrm{~m}^{3} / \mathrm{sec}$ respectively.

Both flood durations and volumes in the two communities showed marked variation, reflecting the extent of differences in geological and topographical properties in these environments. The soil type, vegetation cover and relief of the Oramiriukwa basin are unfavorable to direct runoff generation. Runoff response to rainfall in Ulakwo is slow hence much of the precipitation is lost to infiltration and couple with the fact that the basin is gentler than the Otamiri. Interviews with inhabitants of both communities showed that floodwater in the areas may remain at high stage for weeks and in some cases months interrupting economic activities especially farming and trading. In extreme cases prolonged flood peaks result in submergence of building, roads and footpaths.

Figs 4 and 5 illustrate the magnitudes of floods in studied locations. A general increase in stream flow in the sub-basins was observed from the beginning of rainy season around May attaining peaks between July, August and September and decline towards a minimum around mid-October at the beginning of Dry season. Discharge responded particularly to the seasonal pattern of rainfall. However, in Oramiriukwa (Olakwu community), there is a slight displacement of rainfall peak from discharge peak (Fig 5). The delayed rise in discharge corresponding to rainfall peak may be attributed to the elongated shape of the basin, its gentle slope which creates a lag-time effect, which affects the duration it takes water from the furthest point in the catchment area at the discharge point. Analysis of rainfall-discharge relationship in the study area showed positive correlation with a 0.51 correlation coefficient for Otamiri River and 0.72 for Oramiriukwa River. The coefficients of variability (C.V) for our basins were calculated as 0.07 for Otamiri and 0.56 for Oramiriukwa. These values are consistent with C.V values for river basins in the Tropic and Nigeria (Adejuwon, et al., 1982). 


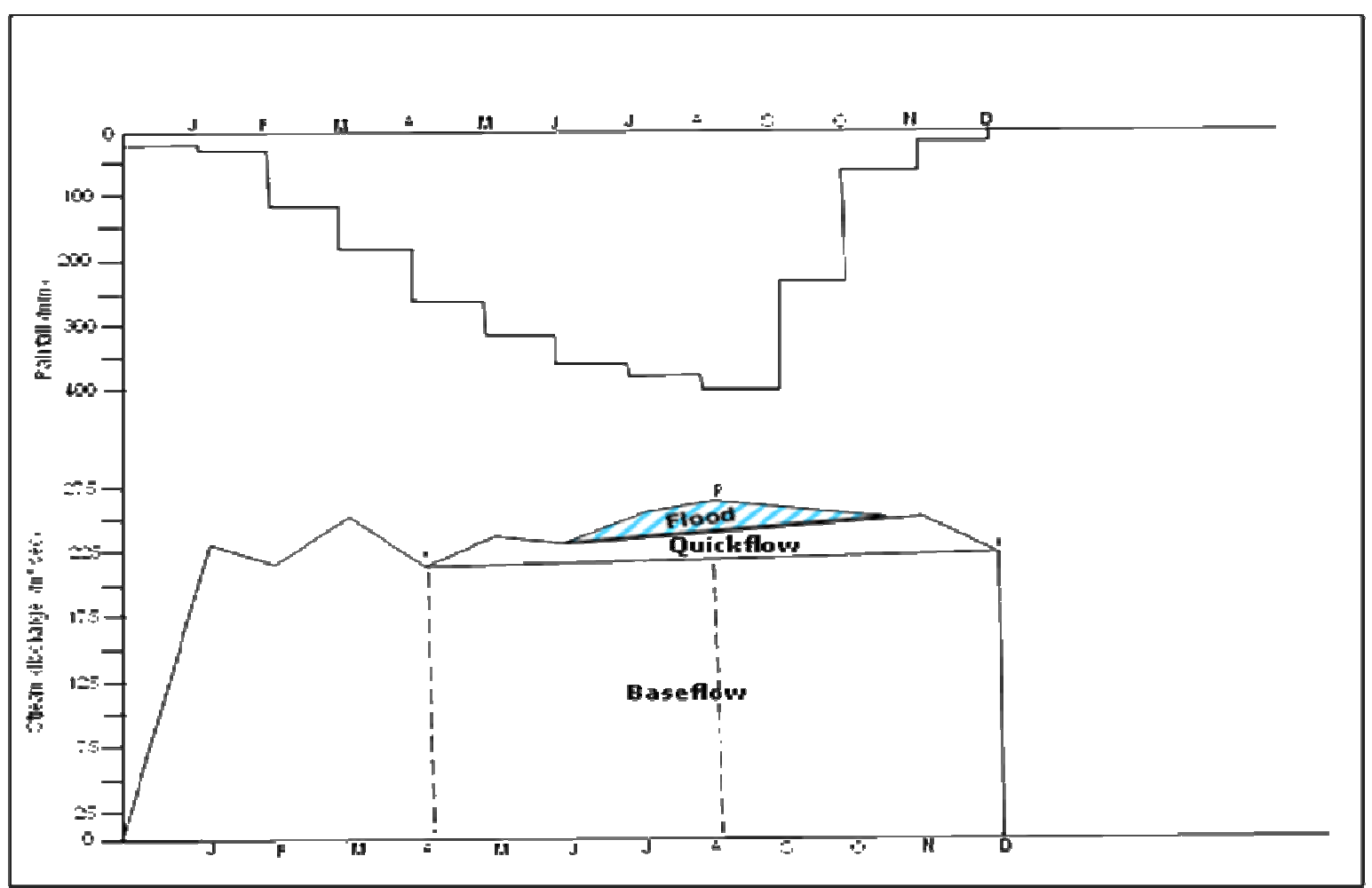

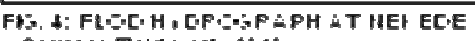

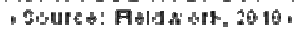

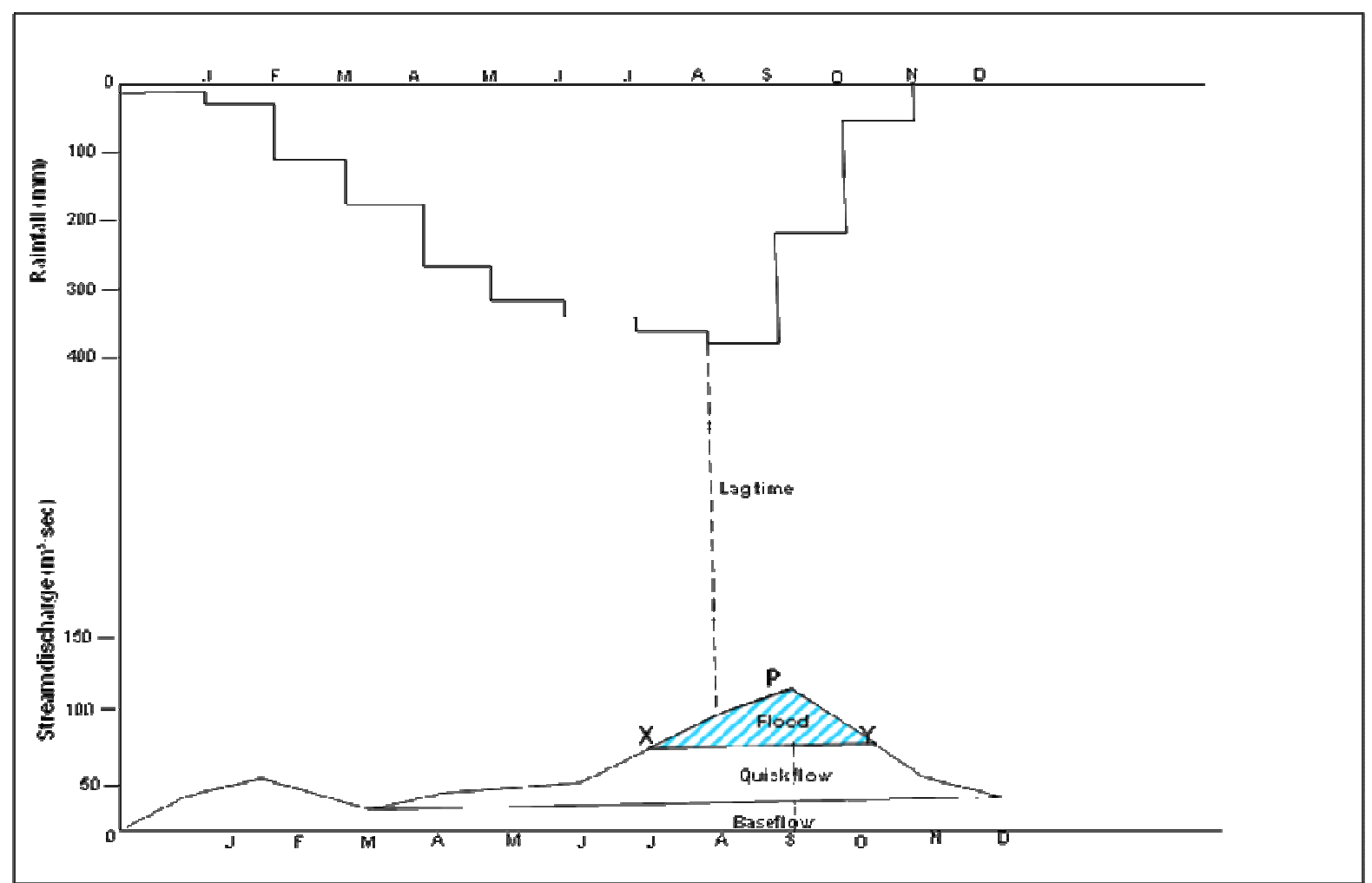

FIG. 5: FLOOD HYDROGRAPH AT ULAKWO

(Soul ce: Fieldwork, 20t0) 
Variability of discharge measures the stream flow fluctuation in a hydrological year. Study has shown that low C.V values depict rivers with relatively even flow throughout the year while C.V values depict basins that have high discharge during the rainy season but dry up during dry season (Aper, 2006). C.V calculated for Oramiriukwa is higher than Otamiri, suggesting that stream flow of Otamiri River is relatively even throughout the year. The fact that C.V values are not uniform suggests that certain parameters in the basins may interfere with the discharge variability index in the study area in different forms. Human activities, evaporation rate and deforestation are some of the factors reported to alter the basin response pattern and annual discharge variability (Berger and Entekhabi, 2001).

In Figs.6, and 7 common flood management strategies in the study area have been summarized. The choice of adaptation method is based principally on previous knowledge of physical nature of flood events and affordability. In Nekede, bearing the flood losses ranked highest. In this method financial, social and psychological burden of flood hazard often fall on the individual. The land elevation which ranked second involves filling the land with sand and stones so as to raise the surface above the level of the probable-maximum flood. Change in land use ranked last. In this method flooded areas are converted to fish farms pending the recession of flood. In Ulakwo, embankment (drainage channels) ranked highest followed by land elevation. Land use change ranked lowest.

Other flood adjustment methods as insurance, flood forecast and early warming, engineering control on river tributaries, legislation and floodplain zoning are not currently being used in both communities. According to Andersen 2001; Kreimer et al., 1999; and Litan, (2000) households, farmers and businesspersons in poor countries cannot easily afford commercial insurance to cover their risks. Cost is not the only limiting factor to insurance uptake; other factors include a lack of formal titles to property, lack of awareness and understanding of the concept of insurance, and reliance on government or international donor relief spending. Lacking savings or access to credit, the alternatives to insurance for many in the developing world include high-interest post disaster loans and arrangements that involve reciprocal exchange, such as kinship ties, community self help and remittances Cohen and Sebstad (2003).

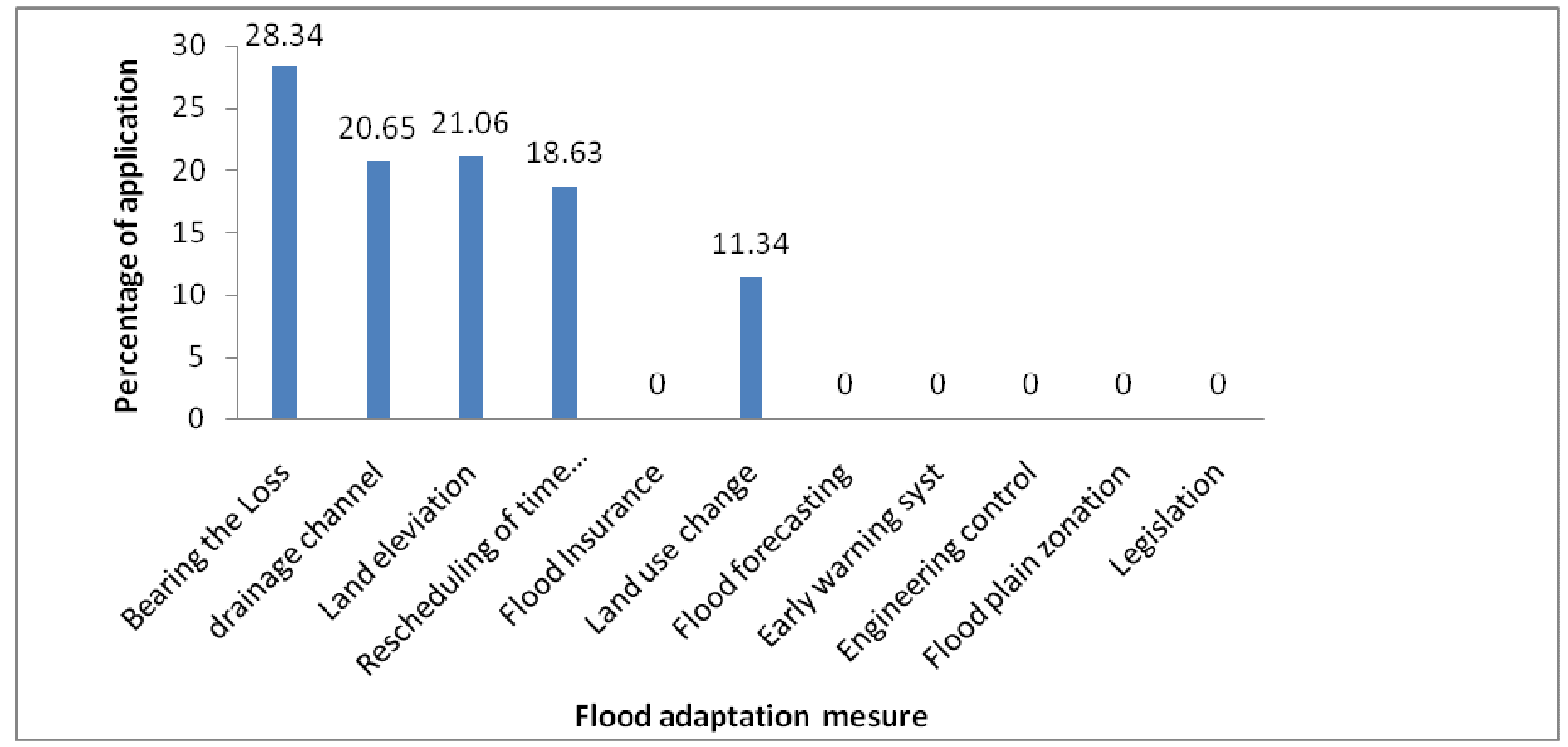

Fig.6: Methods of flood adaptation adopted by inhabitants of Nekede community (Fieldwork, 2010) 


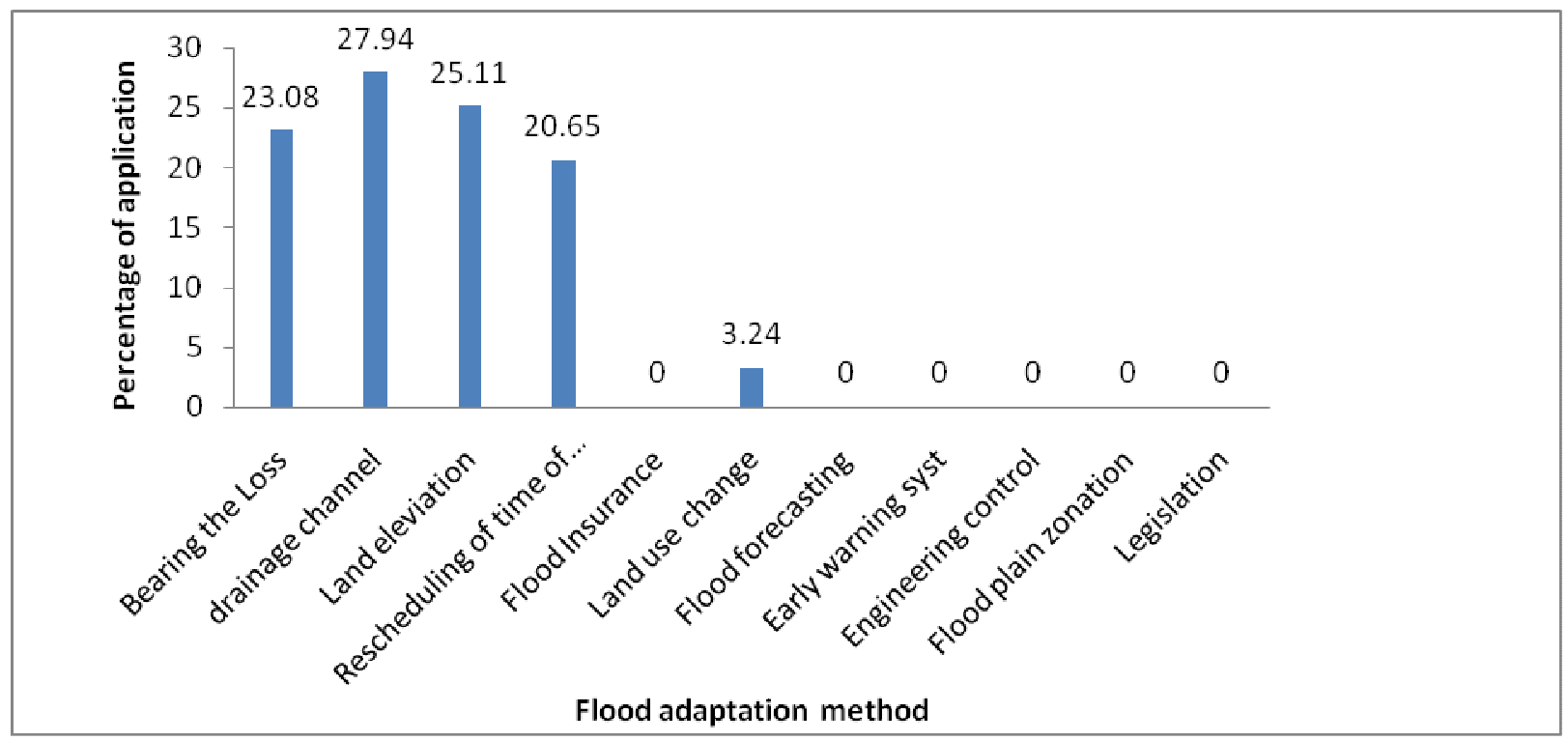

Fig.7: Methods of flood adaptation adopted by inhabitants of Ulakwo community (Fieldwork, 2010)

\section{Conclusion and Recommendations}

In this study, the physical characteristics of flood have been investigated such as onset of flood, time of peak, flood recession, duration, magnitude and index of variability of stream flow. A general increase in flood magnitude in the sub-basins was observed from the beginning of rainy season around May attaining peaks between July, August and September and decline towards a minimum around mid-October at the beginning of Dry season. Flood hydrograph responded particularly to the seasonal pattern of rainfall. Index of stream flow variability calculated for basins under study suggest that Otamiri, River has higher propensity to flood its adjacent area than Oramiukwa River which is highly variable.

Simply bearing flood losses, embankment (drainage channelization), land elevation ranked highest as adjustment methods to flood damage. Other flood adjustment methods such as insurance, flood forecast and early warming, engineering control on river tributaries, legislation and floodplain zoning are not currently being used in both communities. Floodplain zoning and management are thus needed in these communities to improve sustainable natural resource management. Maintaining effective early warning systems, institutions, governance and management frameworks to help confine the potential flood disaster related impacts to manageable proportions are also required. There is need for flood insurance schemes for residents of floodplain in the region for reducing the loss arising from flood. Early warning systems are recommended to provide advance warnings and enhance evacuation plans. Since most flood is not only caused by physical conditions, but also due to socio-economic activities such as logging and the clearing of lands in the catchment areas for agricultural and other purposes, there should be stricter laws governing these activities, and more importantly they should be followed by effective enforcement.

\section{References}

Adejuwon, J.O., Jeje, L.K. and Ogunkoya O.O (1983), Hydrological Response patterns of some Third Order streams on the Basement Complex of Southwestern Nigeria. Hydrological Science Journal 28(3), 377-389.

Adger, W. N., Hughes, T. P., Folke, C., Carpenter, S. R. and Rockstrom, J. (2005), Social-ecological resilience to coastal disasters, Science, 309, 12 August

Anambra- Imo River Basin Development Authority (1984), Hydrological Year Book.

Andersen, T. (2001), Managing Economic Exposures of Natural Disasters. Exploring 
Alternative Financial Risk Management Opportunities and Instruments Inter-American Development Bank, Washington DC

Aper, J.A. (2006), Stream Discharge Characteristics in the Lower Benue Drainage Basin. Unpublished $\mathrm{Ph} . \mathrm{D}$ Thesis, University of Nigeria, Nsukka

Appleton, B. (2002), Climate Changes the Water Rules, Dialogue on Water and Climate, Printfine Ltd., Liverpool, UK.

Berger, K.P. and Entekhabi, D. (2001), Basins hydrological response relations to distributed physiographic descriptors and climate Journal of Hydrology, 247(2-4), 169-18.

Bhanumurthy V and Behera G (2008), Deliverables from space data sets for Disaster Management present and future Trends: The International Archives of the Photogrammetry, Remote sensing and spatial Information sciences vol. xxxvll. Part B8 Beijing 2008

Birkmann, J., Buckle, P., Jaeger, J., Pelling, M., Setiadi, N., Garschagen, M., Fernando, N. and Kropp, J. (2008), Extreme events and disasters; a window of opportunity for change? Analysis of organizational, institutional and political changes, formal and informal responses after mega-disasters, Nat Hazards DOI 10.1007/s11069-008-9319-2

Cohen, M. and Sebstad, J. (2003), Reducing Vulnerability: The Demand for Microinsurance. MicroSave-Africa, Kampala

CRED (2010), Annual Disaster Statistical review 2009, Centre for Research on the Epidemiology of Disasters (CRED), Brussels

Eludoyin, A.O., Akinbode, M.O. and Okuku, E (2007), Combating flood crisis with Geographical Information System: An Example from Akure Southwest en Nigeria. International Symposium on New Direction in Urban water Management UNESCO, Paris 12-14
Hajat, S., Ebi, K. L., Kovats, S., Menne, B., Edwards, S., Haines, A.: (2003), The human health, consequences of flooding in Europe and the implications for public health, J. Appl. Environ. Sci. Public Health, 1(1), 13-21.

Jonkman, S.N. (2005), Global perspectives on loss of Human Life caused by floods. Natural Hazards 34, 341-175.

Kreimer, A., Arnold, M., Freeman, P. (1999), Managing Disaster Risk in Mexico: Market Incentives for Mitigation Investment. World Bank, Washington DC

Litan, R. E. (2000), Catastrophe Insurance and Mitigating Disaster Losses: A Possible Happy Marriage. In Kreimer, A. and Arnold, M. (Eds.): Managing Disaster Risk in Emerging Countries. World Bank, Washinton DC: 187- 193

Moroney, M.J. (1964), Facts from figures, Penguin Books Ltd, Harmondsworth, Middlesex, England Ohl, C. A. and Tapsell, S. (2000), Flooding and human health: dangers posed are not always obvious, Brit. Med. J. 321, 1167-1168.

Ologunorisa, T.E. (2009), Strategies for Mitigation of flood Risk in Niger Delta Nigeria, Journal of Applied science Environmental Management 13(2), 17-22

Orajaka, S.O. (1975), "Geology", in Ofomata, G.E.K. (ed.) Nigeria in Maps: Eastern States, Ethiope Press, Benin City, pp. 5-7.

Soulis, K.X., Valiantzas, J.D., Dercas, N. and Londrs P.A. (2009). Analysis of the runoff generation mechanism for the investigation of the SCS-CN method applicability to a partial area experimental watershed J. Hydrol. And Earth Syst. Discussion (6) pp 373-400.

UNEP (2010) UNEP Year Book, 2010, United Nations Environment Program (UNEP), Nairobi WHO (World Health Organization - Regional office for Europe): 2002, Floods: climate change and adaptation strategies for human health. 